\title{
Upaya Meningkatkan Kompetensi Guru Kelas Dalam Proses Pembelajaran Melalui Supervisi Akademik Berbasis KKG Semester Dua Tahun Pelajaran 2018/2019 di SD Negeri 39 Mataram
}

\author{
Nanik Sugiantarmi \\ Kepala SD Negeri 39 Mataram
}

\begin{abstract}
Abstrak. Yang melatar belakangi diadakannya Penelitian Tindakan Sekolah (PTS) ini yaitu rendahnya kompetensi Guru Kelas dalam proses pembelajaran di kelas. Solusinya yaitu dengan mengefektifkan pelaksanaan supervisi akademik. Permasalahannya apakah pelaksanaan supervisi akademik dapat meningkatkan kompetensi guru dalam proses pembelajaran di kelas semester dua tahun pelajaran 2018/2019 di SD Negeri 39 Mataram. Tujuan penelitian ini adalah untuk mengetahui efektifitas pelaksanaan supervisi akademik dalam upaya meningkatkan kompetensi Guru Kelas dalam pembelajaran di kelas, yang manfaatnya bagi kepala sekolah adalah untuk mengetahui peningkatan kompetensi guru dalam proses pembelajaran. Penelitian ini dilaksanakan selama dua siklus, masing-masing siklus kegiatannya ada empat tahapan yaitu perencanaan, pelaksanaan, observasi, dan refleksi. Indikator keberhasilan dalam penelitian ini adalah; 1) hasil observasi kepala Sekolah maupun observasi guru selama proses pendampingan telah memperoleh skor rata-rata $\geq 4,0,2$ ) hasil akhir $>85 \%$ dari jumlah peserta pendampingan memperoleh nilai ratarata $\geq 80,00$ (kategori baik). Hasil penelitian pada siklus I observasi Kepala Sekolah rata-rata $(3,30)$, observasi guru rata-rata $(3,33)$ dan hasil supervisi akademik guru kelas rata-rata nilai $(63,81)$. Pada siklus II observasi kepala Sekolah rata-rata $(4,60)$, observasi guru rata-rata $(4,67)$ dan hasil supervisi akademik di sasaran rata-rata nilai $(85,49)$. Indikator keberhasilan telah tercapai, penelitian di nyatakan berhasil dan dihentikan pada siklus II. Kesimpulan; Hasil penelitian pada siklus ke 2 menunjukkan peningkatan kompetensi Guru dalam proses pembelajaran di kelas senyatanya. Disarankan agar Kepala Sekolah lainnya melakukan penelitian sejenis dalam upaya peningkatan kompetensi guru, dan kepada guru kelas sejenis agar melakukan proses pembelajaran sesuai dengan skenario yang telah direncanakan dengan baik, tanggung jawab, bersunggungsungguh demi peningkatan prestasi belajar peserta didik sesuai dengan bidang studi/mata pelajaran yang menjadi tanggung jawabnya.
\end{abstract}

Kata kunci : Supervisi Akademis - Kompetensi Guru

\section{PENDAHULUAN}

\section{Latar Belakang}

Di SD Negeri 39 Mataram pada semester dua tahun pelajaran 2018/2019 massih memerlukan 2 (dua) kurikulum yaitu Kurikulum 2013 dan KTSP. Proses pembelajaran bagi 6 (enam) guru kelas I sampai dengan guru kelas VI secara umum telah menggambarkan pembelajaran peserta didik aktif, namun demikian masih belum optimal. Hal ini masih juga dijumpai guru mengajar dengan mendominasi selama proses pembelajaran (guru sentris), sementara peserta didik hanya duduk manis mendengarkan penjelasan guru. Sementara peserta didik kurang diberikan kesempatan untuk bertanya, atau menanyakan sesuatu yang berhubungan dengan materi pembelajaran kepada peserta didik.

Rendahnya kompetensi guru kelass dalam proses pembelajaran, faktor penyebabnya adalah; 1) belum pernah ada guru yang mengikuti pendidikan dan pelatihan (Diklat) yang materinya khusus tentang tata cara mengajar dengan pendekatan, strategi, model, dan metode yang mengarah pada pembelajaran peserta didik aktif, 2) pelaksanaan pembimbingan dari kepala sekolah kepada semua guru masih belum optimal, yang sering dilakukan oleh kepala sekolah adalah pemantauan saja tanpa ada tindak lanjut, dan 3) kegiatan Kelompom Kerja Guru (KKG) di sekolah tidak berjalan lancar, yang ada adalah pembinaan melalui 
rapat-rapat dinass yang materinya berupa instruksi dan himbauan saja bukan membimbing.

Ada beberapa solusi yang bias dilakukan oleh peneliti upaya untuk meningkatkan kompetensi guru dalam proses pembelajaran dikelass, salah satu solusinya adalah dengan melaksanakan supervisi akademik berbasis KKG. Supervisi akademik dalam proses pembelajaran di kelas berbasis KKG memiliki keunggulan bila dibandingkan dengan model pendekatan yang lain. Keunggulan-keunggulan itu adalah; 1) mempermudah proses pembimbingan individual karena bias menggali kekurangan/ketidaktahuan guru dalam melaksanakan proses pembelajaran di kelass senyatanya. Melalui tatap muka secara langsung antara kepala sekolah selaku peneliti dengan guru binaan semua permasalahan dapat diatassi dengan pembimbingan/pendampingan, 2) pekerjaan yang sulit bsa menjaddi mudah kaarena dengan pelaksanaan pendampingan berbasis KKG permasalahan yang dialami dalam proses pembelajaran dapat didiskusikan bersama dalam forum $\mathrm{KKG}$, 3) hubungan internal antara kepala sekolah dengan guru, antara guru kelas bawah dan kelas atass semakin harmonis sehingga mampu menciptakan kebersamaan dan kekeluargaan yang hakiki.

Karena model supervisi dalam proses pembelajaran berbasis KKG ini memiliki beberapa kelebihan dan keunggulan bila dibandingkan dengan model yang lain, maka perlu dibuktikan dengan mengadakan Penelitian Tindakan Sekolah (PTS) dengan judul; "Upaya Meningkatkan Kompetensi Guru Kelas Dalam Proses Pembelajaran Melalui Supervisi Akademik Berbasis KKG Semester Dua Tahun Pelajaran 2018/2019 di SD Negeri 39 Mataram".

\section{Rumusan Masalah}

"Bagaimana melaksanakan supervisi akademik berbasis KKG upaya meningkatkan kompetensi guru dalam proses pembelajaran semester dua tahun pelajaran 2018/2019 di SD Negeri 39 Mataram?".

\section{Tujuan Penelitian}

"Untuk mengetahui efektifitas pelaksanaan supervisi akademik dalam proses pembelajaran di kelas senyatanya, upaya meningkatkan kompetensi guru kelas semester dua tahun pelajaran 2018/2019 di SD Negeri 39 Mataram."

\section{Manfaat Penelitian}

1. Bagi Kepala Sekolah, sangat bermanfaat dalam rangka melaksanakan pembimbingan bagi guru kelas di sekolah binaannya khususnya tentang tata cara mengajar yang baik dan benar melalui kegiatan supervisi akademik.

2. Bagi guru, sangat bermanfaat dalam upaya meningkatkan kompetensi dalam proses pembelajaran di kelas senyatanya sehingga bisa menjadi guru yang profesional dan mampu mengajar peserta didik dengan skenario yang telah ditetapkan pada Rencana Pelaksanaan Pembelajaran (RPP).

\section{KAJIAN PUSTAKA \\ Kerangka Teoritis \\ KOMPETENSI GURU}

Kompetensi dalam bahasa Indonesia merupakan serapan dari bahasa Inggris, competence yang berarti kecakapan dan kemampuan. Kompetensi adalah kumpulan pengetahuan, perilaku, dan ketrampilan yang harus dimiliki guru untuk mencapai tujuan pembelajaran dan pendidikan. Kompetensi di peroleh melalui pendidikan, pelatihan, dan belajar mandiri dengan memanfaatkan sumber belajar. Menurut UU No.14 tahun 2005 tentang Guru dan Dosen Pasal 1 Ayat 10, disebutkan: Kompetensi adalah seperangkat pengetahuan, ketrampilan, dan perilaku yang harus dimiliki, dihayati, dan dikuasai oleh guru atau dosen dalam melaksanakan tugas keprofesionalan.

Kompetensi tidak hanya terkait dengan kesuksesan seseorang dalam menjalankan tugasnya, tetapi apakah ia juga berhasil bekerja sama dalam sebuah tim, sehingga tujuan lembaganya tercapai sesuai harapan. Kompetensi adalah kemampuan untuk mencapai tujuan organisasi, tujuan lembaga hanya munngkin tercapai ketika individu dalam lembaga itu bekerja sebagai tim sesuai standar yang diterapkan.

Dari beberapa penjelasan mengenai kompetensi dapat ditarik kesimpulan bahwa 
kompetensi merupakan kemampuan seseorang yang meliputi pengetahuan, keterampilan, dan sikap, yang dapat diwujudkan dalam hasil kerja nyata yang bermanfaat bagi diri dan lingkungannya. Ketiga aspek kemampuan ini saling terkait dan mempengaruhi satu sama lain. Kondisi fisik dan mental serta spiritual seseorang besar pengaruhnya terhadap produktivitas kerja seseorang, maka tiga aspek ini harus dijaga pula sesuai standar yang disepakati. Sedangkan guru, dalam Kamus Besar Bahasa Indonesia (KBBI) berarti seseorang yang memiliki profesi mengajar. Sedangkan di dalam bahasa Arab guru bisa disebut dengan $A l$ - Mudarris yang dapat diartikan sebagai seseorang yang mengajar atau memberikan pengajaran atau juga dapat disebut Ustadz yang berarti seseorang yang mengajar dalam bidang Agama Islam.

Dari kedua penjelasan mengenai kompetensi dan guru, dapat diartikan kompetensi guru merupakan perpaduan antara kemampuan personal, keilmuan, teknologi, sosial, dan spiritual yang secara kaffah membentuk kompetensi standar profesi guru, yang mencakup penguasaan materi, pemahaman terhadap peserta didik, pembelajaran yang mendidik, pengembangan pribadi dan profesionalisme.

Guru adalah profesi yang ditandai dengan dimilikinya suatu kompetensi, guru yang berkompetensi adalah seorang yang memiliki ketrampilan serta kemampuan sebagai guru dalam melaksanakan tugasnya. Kompetensi guru merupakan suatu ukuran yang ditetapkan atau dipersyaratkan dalam bentuk penguasaan pengetahuan dan perilaku perbuatan bagi seorang guru agar berkelayakan untuk menduduki jabatan fungsional sesuai dengan bidang tugas, kualifikasi, dan jenjang pendidikan.

$$
\text { Kompetensi guru merupakan }
$$
perpaduan antara kemampuan personal, keilmuan, teknologi, sosial, dan spiritual yang secara kaffah membentuk kompetensi dasar profesi guru, yang mencakup penguasaan materi, pemahaman terhadap peserta didik, pembelajaran yang mendidik, pengembangan pribadi dan profesionalitas.
Kompetensi guru akan mengantarkannya menjadi guru profesional yang diidamkan oleh anak didik. Seseorang memiliki bidang keahlian jika ia memiliki kompetensi ilmu yang memadai dan mendalam. Kompetensi ilmu akan melahirkan kompetensi moral karena ilmu dan moral adalah dua sisi yang tidak bisa dipisahkan. Mengingat sebuah kalimat bijak, "Ilmu tanpa amal seperti pohon tanpa buah", tidak ada manfaatnya bagi diri sendiri. "Ilmu tanpa amal seperti lebah tanpa madu", selain tidak ada manfaatnya, juga berbahaya karena berpotensi menyakiti orang lain dengan ilmunya.

Dapat ditarik kesimpulan, kompetensi guru adalah kemampuan yang ditampilkan oleh guru dalam melaksanakan kewajibannya memberikan pelayanan pendidikan kepada masyarakat. Kemampuan yang meliputi yaitu kemampuan personal, keilmuan, teknologi, sosial, dan spiritual yang secara kaffah membentuk kompetensi dasar profesi guru, yang mencakup penguasaan materi, pemahaman terhadap peserta didik, pengembangan pribadi dan profesionalitas.

\section{Supervisi Akademik}

Supervisi akademik adalah serangkaian kegiatan membantu guru mengembangkan kemampuannya mengelola proses pembelajaran demi pencapaian tujuan pembelajaran Glickman (1981). Sementara itu, Daresh (1989) menyebutkan bahwa supervisi akademik merupakan upaya membantu guru-guru mengembangkan kemampuannya mencapai tujuan pembelajaran.

Dengan demikian, esensi supervisi akademik itu sama sekali bukan menilai unjuk kerja guru dalam mengelola proses pembelajaran, melainkan membantu guru mengembangkan kemampuan profesionalismenya. Meskipun demikian, supervisi akademik tidak bisa terlepas dari penilaian unjuk kerja guru dalam mengelola pembelajaran. Apabila di atas dikatakan, bahwa supervisi akademik merupakan serangkaian kegiatan membantu guru mengembangkan kemampuannya mengelola proses pembelajaran, maka menilai unjuk kerja guru dalam mengelola proses pembelajaran merupakan salah satu kegiatan 
yang tidak bisa dihindarkan prosesnya (Sergiovanni, 1987). Penilaian unjuk kerja guru dalam mengelola proses pembelajaran sebagai suatu proses pemberian estimasi kualitas unjuk kerja guru dalam mengelola proses pembelajaran, merupakan bagian integral dari serangkaian kegiatan supervisi akademik. Apabila dikatakan bahwa supervisi akademik merupakan serangkaian kegiatan membantu guru mengembangkan kemampuannya, maka dalam pelaksanaannya terlebih dahulu perlu diadakan penilaian kemampuan guru, sehingga bisa ditetapkan aspek yang perlu dikembangkan dan cara mengembangkannya.

Tujuan supervisi akademik adalah membantu guru mengembangkan kemampuannya mencapai tujuan pembelajaran yang dicanangkan bagi muridmuridnya (Glickman, 1981). Melalui supervisi akademik diharapkan kualitas akademik yang dilakukan oleh guru semakin meningkat (Neagley, 1980). Pengembangan kemampuan dalam konteks ini janganlah ditafsirkan secara sempit, semata-mata ditekankan pada peningkatan pengetahuan dan keterampilan mengajar guru, melainkan juga pada peningkatan komitmen (commitmen) atau kemauan (willingness) atau motivasi (motivation) guru, sebab dengan meningkatkan kemampuan dan motivasi kerja guru, kualitas pembelajaran akan meningkat.

Berkaitan dengan prinsip-prinsip supervisi akademik, akhir-akhir ini, beberapa literatur telah banyak mengungkapkan teori supervisi akademik sebagai landasan bagi setiap perilaku supervisi akademik. Beberapa istilah, seperti demokrasi (democratic), kerja kelompok (team effort), dan proses kelompok (group process) telah banyak dibahas dan dihubungkan dengan konsep supervisi akademik. Pembahasannya semata-mata untuk menunjukkan kepada kita bahwa perilaku supervisi akademik itu harus menjauhkan diri dari sifat otoriter, di mana supervisor sebagai atasan dan guru sebagai bawahan. Begitu pula dalam latar sistem persekolahan, keseluruhan anggota (guru) harus aktif berpartisipasi, bahkan sebaiknya sebagai prakarsa, dalam proses supervisi akademik, sedangkan supervisor merupakan bagian darinya. Semua ini merupakan prinsip-prinsip supervisi akademik modern yang harus direalisasikan pada setiap proses supervisi akademik di sekolah-sekolah.

Para pakar pendidikan telah banyak menegaskan bahwa seseorang akan bekerja secara profesional apabila ia memiliki kompetensi yang memadai. Seseorang tidak akan bisa bekerja secara profesional apabila ia hanya memenuhi salah satu kompetensi di antara sekian kompetensi yang dipersyaratkan. Kompetensi tersebut merupakan perpaduan antara kemampuan dan motivasi. Betapapun tingginya kemampuan seseorang, ia tidak akan bekerja secara profesional apabila ia tidak memiliki motivasi kerja yang tinggi dalam mengerjakan tugastugasnya. Sebaliknya, betapapun tingginya motivasi kerja seseorang, ia tidak akan bekerja secara profesional apabila ia tidak memiliki kemampuan yang tinggi dalam mengerjakan tugas-tugasnya.

Supervisi akademik yang baik harus mampu membuat guru semakin kompeten, yaitu guru semakin menguasai kompetensi, baik kompetensi kepribadian, kompetensi pedagogik, kompetensi profesional, dan kompetensi sosial. Oleh karena itu, supervisi akademik harus menyentuh pada pengembangan seluruh kompetensi guru. Menurut Neagley (1980) terdapat dua aspek yang harus menjadi perhatian supervisi akademik baik dalam perencanaannya, pelaksanaannya, maupun penilaiannya.

\section{Proses Pembelajaran}

Proses adalah suatu cara, metode maupun teknik yang digunakan untuk penyelenggaraan atau pelaksanaan dari suatu hal tertentu, Ahyari (2002: 65). Proses dalam pembelajaran dapat diartikan bahwa suatu cara atau metode untuk melaksanakan kegiatan pembelajaran yang terjadi didalam lembaga pendidikan antara pendidik dan peserta didik.

Proses pembelajaran adalah seluruh kegiatan yang dirancang dan dilaksanakan untuk membelajarkan peserta didik. Pada lembaga pendidikan, proses pembelajaran diselengarakan secara interaktif, inspiratif, menyenangkan, menantang, memotivasi peserta didik untuk selalu berpartisipasi aktif 
sesuai dengan bakat dan minat serta psikologis peserta didik, Mulyasana (2012: 155). Berdasarkan Peraturan Menteri Pendidikan Nasional (Permendiknas) Nomor 41 tahun 2007 tentang standar proses untuk satuan pendidikan dasar dan menengah, bahwa standar proses berisi tentang kriteria minimum proses pembelajaran yang berlajan pada satuan pendidikan dasar dan menengah diseluruh wilayah hukum Negara Kesatuan Republik Indonesia. Standar proses yang dikeluarkan oleh Permendiknas yaitu, standar plaksanaan proses pembelajaran, penilaian pembelajaran, dan pengawasan hasil belajar untuk terlaksananya proses pembelajaran yang efektif dan efisien.

\section{Kkg}

Kelompok Kerja Guru (KKG) adalah wadah kerja sama guru-guru dalam satu gugus, dalam upaya meningkatkan kemampuan profesional mereka. Fungsi utamanya adalah menampung dan memecahkan masalah yang dihadapi dalam KBM melalui pertemuan diskusi, pengajaran contoh, demonstrasi penggunaan dan pembuatan alat peraga. KKG tersebut berorientasi kepada peningkatan kualitas pengetahuan, penguasaan materi, teknik mengajar dan lain-lain yang berfokus pada penciptaan KBM yang efektif. Untuk menunjang kelancaran pelaksanaannya, KKG juga memiliki organisasi kepengurusan, yang terdiri dari Ketua, sekretaris, bendahara, dan anggota. Dibina oleh seorang pengawas serta dibantu oleh beberapa orang guru yang dipandang mempunyai keahlian dalam bidang ilmu tertentu sebagai pemandu bidang studi atau mata pelajaran

Untuk mendapatkan pengakuan sebagai guru yang baik dan berhasil, maka guru berusahalah tampil di muka kelas dengan prima. Setiap guru bertanggung jawab untuk meningkatkan kompotensi profesionalnya. Guru bertanggung jawab secara profesional untuk terus meningkatkan kemampuannya. Dengan demikian, peningkatan kemampuan profesional guru menjadi tugas dan bertanggung jawab guru yang bersangkutan untuk mengupayakannya. Namun demikian tidak semua guru dapat melakukannya secara efektif, oleh karena itu, diperlukan sarana yang dapat menolong mereka. Kelompok kerja guru (KKG) merupakan salah satu sarana atau wadah yang dapat dimanfaatkan guru-guru untuk meningkatkan kemampuan profesionalnya.

Adapun kegiatan yang dilakukan pada pertemuan KKG tersebut adalah.

a. Memperdalam pengetahuan dan penguasaan didaktik metodik.

b. Mengupayakan pemecahan berbagai masalah yang berkaitan dengan proses belajar mengajar. c. Membuat dan mengujip enggunaan alat peraga.

c. Berlatih menyusun berbagai administrasi pengajaran.

d. Berlatih menerapkan metode mengajar tertentu.

e. Bertukar informasi mengenai berbagai masalah dan gagasan-gagasan baru khususnya yang berkaitan dengan proses belajar mengajar.

f. Menginventarisir berbagai bentuk budaya daerah dan ragam pola kehidupan sosial yang akan diangkat menjadi materi pengajaran muatan lokal.

Dengan berbagai kegiatan tersebut di atas, diharapkan kemampuan profesional guru-guru dapat ditingkatkan. Dengan kata lain, kemampuan profesional guru-guru bisa ditingkatkan melalui berbagai kegiatan yang dilakukan di KKG. Penelitian yang mengkaji tentang KKG ini belum begitu banyak dilakukan terutama apabila dikaitkan dengan kemampuan profesional guru-guru sebagai indikator dari keberhasilan pelaksanaan $\mathrm{KKG}$ tersebut.

\section{Hipotesis Tindakan}

"pelaksanaan supervisi akademik dapat meningkatkan kompetensi guru kelas SD Negeri 39 Mataram dalam proses pembelajaran di kelas semester dua tahun pelajaran 2018/2019"

\section{METODE PENELITIAN}

\section{Jenis Penelitian}

Setting Penelitian

Penelitian Tindakan Sekolah (PTS) ini dilaksanakan di SD Negeri 39 Mataram dengan mengefektifkan pelaksanaan supervisi akademik bagi enam orang guru kelas. 
Jenis Tindakan : supervisi akademik dalam proses pembelajaran di kelas senyatanya

Dampak yang diharapkan : meningkatkan kompetensi guru kelas SD Negeri 39 Mataram dalam melaksanakan proses pembelajaran di kelas senyatanya.

\section{Perencanaan Tindakan}

\section{Jenis tindakan yang dilakukan}

- Kepala Sekolah menyampaikan hasil pemantauan terhadap 6 (enam) guru kelas dalam proses pembelajaran di kelas ditemukan masih mengalami kendala.

- Kepala Sekolah menyampaikan materi pendampingan yang terfokus pada tata cara mengajar yang baik dan benar.

\section{Skenario Supervisi Akademik}

Untuk mendapatkan gambaran yang jelas tentang skenario pelaksanaan tindakan dalam kegiatan supervisi akademik ini dapat digambarkan sebagai berikut:

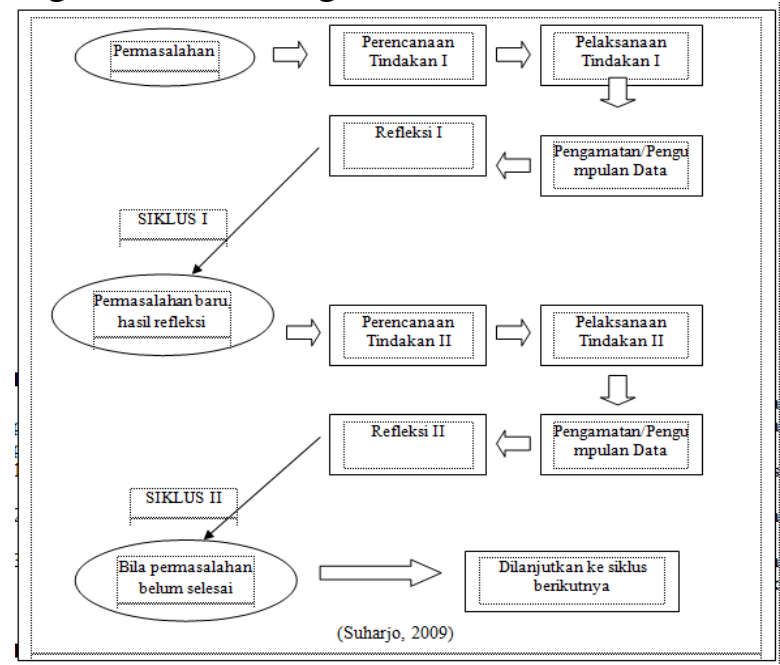

\section{Pelaksanaan Tindakan}

Dalam penelitian ini peneliti melakukan supervisi akademik yang terfokus pada pelaksanaan proses pembelajaran di kelas senyatanya. Jenis instrumen yang digunakan dalam penelitian ini sebagai berikut:

1. Instrumen pengamatan/observasi Kepala sekolah yang dilakukan oleh Pengawas pembimbing selaku observer.

2. Instrumen pengamatan/observasi guru selama kegiatan penjelasan teknik dilakukan oleh Kepala sekolah sekaligus sebagai peneliti.
3. Instrumen penilaian hasil kerja individual dalam proses pembelajaran di kelas dilakukan oleh peneliti, ini sekaligus sebagai tolak ukur keberhasilan selama supervisi akademik sesuai indikator kinerja yang telah ditetapkan.

\section{Evaluasi dan Refleksi Tindakan}

Tahapan ini adalah melakukan kajian dan penilaian proses tindakan dan hasil atau dampak tindakan terhadap perilaku sasaran (Nana Sudjana, 2009; 39). Adapun kegiatan riilnya adalah : 1) membandingkan hasil pengamatan aktifitas dari ke 6 (enam) guru kelas selama proses bimbingan selama supervisi akademik, 2) membandingkan perolehan nilai hasil kegiatan pembelajaran di kelas senyatanya dengan indikator keberhasilan yang telah ditetapkan.

\section{SIKLUS TINDAKAN}

Dalam penelitian tindakan sekolah (PTS) ini direncanakan sebanyak dua siklus, masing-masing siklus dua kali pertemuan. Masing-masing siklus terdiri atas empat tahapan kegiatan yaitu tahap perencanaan, pelaksanaan, pengamatan, dan refleksi. Untuk mendapatkan gambaran secara rinci kegiatan masing-masing tahap dapat dijelaskan sebagai berikut:

\section{SIKLUS I}

\section{Tahap I : Perencanaan Tindakan}

1. Menyusun materi tentang supervisi akademik

2. Menetapkan skneario dan langkah-langkah pendampingan

3. Menyusun instrumen observasi Kepala sekolah dan observasi guru

4. Menentukan jadwal kegiatan supervisi akademik

5. Menyusun pedoman analisa data hasil observasi dan hasil supervisi akademik

\section{Tahap II : Pelaksanaan Tindakan}

a) Kegiatan pendampingan

1. Menyampaikan materi tentang tata cara mengajar yang baik dan benar

2. Melaksanakan tanya jawab tentang tata cara mengajar yang baik dan benar

3. Memberikan bimbingan terhadap peserta yang mengalami kesulitan 

4. Memberikan solusi terhadap permasalahan yang dihadapi guru
5. Memberikan penguatan/reward
6. Memberikan tugas individual

b) Kegiatan supervisi akademik

Secara terjadwal dan bergiliran peneliti melakukan supervisi akademik di kelas tempat guru mengajar

\section{Tahap III : Pengamatan/pengumpulan Data}

1. Pengamatan terhadap aktifitas guru selama pembimbingan

2. Pengamatan terhadap guru dalam proses pembelajaran (supervisi akademik)

3. Menilai hasil tampilan guru selama proses pembelajaran di kelas

\section{Tahap IV : Refleksi}

1. Renungan atas data hasil observasi dan hasil penilaian selama proses pembelajaran di kelas

2. Pengolahan data hasil penelitian dan mencocokkan dengan indikator keberhasilan

3. Rencana perbaikan dan penyempurnaan

4. Memberikan penguatan atas hasil yang diperolehnya.

5. Rencana tindak lanjut

\section{SIKLUS II}

Jenis kegiatan pada siklus II ini pada dasarnya sama dengan siklus I, bedanya hanya terjadi perbaikan/penyempurnaan dalam pelaksanaannya.

\section{Indikator Keberhasilan}

- Hasil observasi Kepala sekolah maupun observasi guru selama proses pendampingan telah memperoleh skor rata-rata $\geq 4,0$ (kategori baik/kategori aktif)

- Kompetensi pedagogik dalam proses pembelajaran dinyatakan berhasil jika $\geq$ 85\% dari jumlah guru kelas memperoleh nilai rata-rata $\geq 80,00$ (kategori baik).

\section{LAPORAN HASIL DAN PEMBAHASAN \\ Laporan Hasil \\ SIKLUS I}

\section{Tahap Perencanaan}

Pada tahapan ini peneliti telah berhasil: 1) menyusun materi tentang supervisi akademik, 2) menetapkan skenario dan langkah-langkah pendampingan, 3) menyusun instrumen observasi Kepala sekolah observasi guru, dan instrumen kegiatan supervisi akademik, 4) menentukan jadwal kegiatan supervisi akademik yang terbagi menjadi 2 (dua) pertemuan, 5) menyusun pedoman analisa data hasil observasi dan hasil supervisi akademik, Tahap Pelaksanaan

Pada tahapan ini peneliti melakukan 2 (dua) kegiatan yaitu kegiatan pendampingan/pembimbingan secara klasikal, dan kegiatan kedua adalah pelaksanaan supervisi akademik di kelas senyatanya.

\section{Tahap Pengumpulan/Pengumpulan Data}

Observasi kepala sekolah memperoleh skor rata-rata sebesar 3,30, observasi guru memperoleh skor rata-rata sebesar 3,33, dan hasil supervise akademik di kelas memperoleh nilai rata-rata sebesar 63,81.

\section{Tahap Refleksi}

Pada tahap ini peneliti melakukan beberapa kegiatan yang merupakan tahapan akhir dari pelaksanaan siklus I, yaitu kegiatan perencanaan, pelaksanaan, dan observasi. Adapun kegiatan secara rinci meliputi: 1) renungan atas data hasil observasi dan hasil pengamatan selama proses pembelajaran di kelas senyatanya, 2) pengolahan data hasil penelitian dan mencocokkan dengan indikator keberhasilan, 3) rencana perbaikan dan penyempurnaan, 4) memberikan penguatan atas hasil yang diperolehnya, dan 5) rencana tindak lanjut.

\section{SIKLUS II}

\section{Tahap Perencanaan}

Pada tahapan ini peneliti kegiatannya masih mengacu pada siklus I yakni merencanakan: 1) penyusunan materi tentang supervisi akademik, 2) menetapkan skenario dan langkah-langkah pendampingan, 3) menyusun instrumen observasi Kepala sekolah dan observasi guru, 4) menentukan jadwal kegiatan supervisi akademik, 5) menyusun pedoman analisa data hasil observasi dan hasil supervisi akademik.

\section{Tahap Pelaksanaan}

Pada tahapan ini peneliti kegiatannya adalah masih sama dengan siklus I, bedanya pada siklus II ini pelaksanaannya lebih dioptimalkan karena kesalahan-kesalahan dan kekurangan pada siklus I sudah di deteksi dan sudah dicari jalan keluarnya. 


\section{Tahap Pengamatan/Pengumpulan Data}

Observasi kepala sekolah memperoleh skor rata-rata sebesar 4,60, observasi guru memperoleh skor rata-rata sebesar 4,67, dan hasil supervise akademik di kelas memperoleh nilai rata-rata sebesar 85,49.

\section{Tahap Refleksi}

Pada tahapan ini peneliti melakukan kegiatan: 1) merenung dan membandingkan hasil tindakan siklus I dengan hasil tindakan siklus sebelumnya, 2) merekap hasil tindakan berupa hasil observasi kepala sekolah, observasi guru, dan hasil supervisi akademik di kelas senyatanya, kemudian 3) mencocokkan dengan indikator yang telah ditetapkan, 4) Rencana tindak lanjut hasil penelitian

\section{Pembahasan}

\section{SIKLUS I}

\section{Tahap Perencanaan}

Ada beberapa kendala yang dihadapi dalam kegiatan ini, diantaranya dalam penyusunan materi tentang supervisi akademik, persiapan skenario tindakan selama pendampingan, penyusunan instrumen observasi Kepala sekolah dan instrumen observasi peserta pendampingan, penentuan jadwal supervisi akademik bagi 6 (enam) guru kelas dalam proses pembelajaran di kelas senyatanya, dan penyusunan pedoman analisa data hasil observasi Kepala sekolah, observasi guru dalam proses pembelajaran di kelas dan hasil supervisi akademik dari ke 6 (enam) guru kelas. Tetapi setelah berkonsultasi dengan pembimbing akhirnya kendala yang dihadapi dapat diatasi dengan baik, dan kegiatan pun dapat berjalan dengan lancar.

\section{Tahap Pelaksanaan}

Dalam melaksanakan pendampingan klasikal tentang perlunya pendampingan dan penyampaian materi tentang supervisi akademik yang kegiatan nyatanya menjelaskan bagaimana cara mengajar yang baik dan benar sesuai dengan instrumen yang telah ditetapkan, serta pelaksanaan tanya jawab kepada peserta mengalami hambatan yaitu yang seharusnya pukul 08.00 dimulai tetapi karena sebagian guru ada yang masih ada yang mengajar, ada yang memberikan tugas kepada peserta didik yang berakibat molornya pelaksanaan pendampingan klasikal. Solusinya peneliti mengundurkan waktu pelaksanaan +15 menit, setelah semua guru berkumpul baru dilaksanakan pendampingan klasikal. Hasilnya semua rencana dapat terlaksana tanpa menambah waktu yang telah disiapkan.

\section{Tahap Pengamatan/Pengumpulan Data}

Pengamatan/observasi Kepala sekolah oleh pengawas pembimbing selaku observers pada kegiatan pendampingan klasikal (pertemuan I) berjalan lancar, artinya tidak ada kendala.Hasil skor rata-rata yang diraih oleh Kepala sekolah/peneliti $(3,30)$ kategori cukup dari indikator keberhasilan yang diharapkan yaitu $\geq 4,00$ (kategori aktif). Sementara itu hasil observasi guru oleh peneliti selama proses pendampingan klasikal, dilihat dari aktifitas dari ke enam guru kelas memperoleh rata-rata $(3,33)$ kategori cukup dari indikator keberhasilan yang direncanakan yaitu $\geq 4,00$ (kategori aktif). Perolehan nilai rata-rata hasil supervisi akademik dari 6 (enam) guru kelas diperoleh hasil $(63,81)$ dengan presentase ketuntasan $0 \%$, Tahap Refleksi

Setelah semua perolehan data dianalisis dan di cocokkan dengan indikator keberhasilan, diperoleh data sebagai berikut: Hasil Observasi Kepala Sekolah $(3,30)$, hasil observasi guru $(3,33)$, dan hasil supervise akademik $(63,81)$.

\section{SIKLUS II}

\section{Tahap Perencanaan}

Pada tahapan ini peneliti melaksanakan kegiatan seperti halnya pada siklus I yaitu: 1) penyusunan materi pendampingan masih ada kendala yaitu materi yang disajikan masih sama dengan materi siklus I, faktor penyebabnya peneliti masih belum memahami materi apa lagi yang harus disusun, solusinya peneliti meminta petunjuk kepada pengawas pembimbing untuk mendapatkan solusi, setelah diberikan pengarahan akhirnya materi pendampingan dapat di buat lebih simpel dan lebih praktis sehingga guru tidak mengalami kesulitan dalam memahami materi tentang cara cara mengajar yang baik dan benar, 2) penyusunan skenario tindakan yang sudah dibuat pada siklus I ditetapkan karena dianggap tidak ada 
kendala yang mengganggu kegiatan supervisi akademik, 3) penyusunan instrumen observasi kepala sekolah, observasi guru masih mengacu pada instrumen pada siklus I, 4) penentuan jadwal kegiatan juga tidak ada kendala, dan 5) penyusunan pedoman analisa data juga masih mengacu pada siklus I

\section{Tahap Pelaksanaan}

Peneliti melakukan pendampingan klasikal dengan mengoptimalkan tindakan nyata terutama kesalahankesalahan/kekurangan yang terjadi pada siklus I lebih dioptimalkan, sehingga dalam pelaksanaan pendampingan pada siklus II ini berjalan lancar tanpa hambatan yang berarti. Pelaksanaan supervisi akademik di kelas senyatanya berjalan sesuai jadwal yang telah ditetapkan. Semua guru mengajar dikelas tepat waktu namun perolehan hasil masih belum memperoleh nilai rata-rata yang diharapkan.

\section{Tahap Pengamatan/Pengumpulan Data}

Hasil pengamatan penampilan Kepala sekolah/peneliti yang dilakukan oleh observer, maupun hasil pengamatan guru selama proses pendampingan oleh kepala sekolah diperoleh data sebagai berikut: Hasil Observasi Kepala Sekolah (4,60), hasil observaasi guru $(4,67)$. Perolehan hasil supervisi akademik pada siklus II memperoleh skor rata-rata $(85,49 / \mathrm{kategori}$ baik) dan prosentasi ketuntasan $100 \%$. Hasil ini sudah memenuhi indikator keberhasilan yang telah ditetapkan, yaitu $85 \%$ dari jumlah peserta memperoleh nilai rata-rata $\geq 80,00$ (kategori baik). Oleh karena itu penelitian dihentikan pada siklus II.

\section{Tahap Refleksi}

Hasil observasi kepala sekolah memperoleh skor rata-rata $(4,60)$ dari $\geq 4,00$ yang ditetapkan, sementara hasil observasi guru juga mengalami peningkatan yaitu memperoleh skor rata-rata $(4,67)$ dari indikator keberhasilan keberhasilan yang ditetapkan yaitu $\geq 4,00$. Sedangkan hasil supervisi akademik kindikator kinerja yang ditetapkan yaitu $\geq 80,00$ nilai rata-rata yang diperoleh mencapai $(85,49)$, ini artinya indikator keberhasilan telah terlampaui.

Karena indikator keberhasilan sudah dapat tercapai maka penelitian Tindakan
Sekolah (PTS) dinyatakan "BERHASIL" dan dapat dihentikan pada siklus ke II. Keberhasilan ini merupakan bukti nyata bahwa pelaksanaan supervisi akademik di SD Negeri 39 Mataram pada semester dua tahun pelajaran 2018/2019 dapat meningkatan kompetensi guru kelas dalam proses pembelajaran di kelas senyatanya.

\section{Kesimpulan}

Pelaksanaan supervisi akademik dalam proses pembelajaran di kelas senyatanya dapat meningkatkan kompetensi guru kelas dalam melaksanakan pembelajaran di kelas berdasarkan kurikulum 2013 semester dua tahun pelajaran 2018/2019 di SD Negeri 39 Mataram. Hal ini dapat dibuktikan bahwa data dari siklus I, II, dan III. Secara berturutturut mengalami peningkatan.

Data riil hasil tindakan selama 2 siklus dapat dipaparkan dengan jelas sebagai berikut:

\begin{tabular}{|c|l|c|c|c|c|}
\hline No & \multicolumn{1}{|c|}{ Jenis Kegiatan } & $\begin{array}{c}\text { Indikator } \\
\text { Keberhasilan }\end{array}$ & $\begin{array}{c}\text { Siklus } \\
\text { I }\end{array}$ & $\begin{array}{c}\text { Siklus } \\
\text { II }\end{array}$ & Keterangan \\
\hline 1. & Hasil Observasi Kepala Sekolah & $\geq 4,00$ & 3,30 & 4,60 & Tuntas \\
\hline 2. & Hasil Observasi Guru & $\geq 4,00$ & 3,33 & 4,67 & Tuntas \\
\hline 3. & Hasil Supervisi Akademik & $\geq 80,00$ & 63,81 & 85,49 & Tuntas \\
\hline
\end{tabular}

\section{Saran}

- Kepala Sekolah sejawat di lingkungan pembinaan Dinas Pendidikan Kota Mataram agar mencoba melakukan penelitian Tindaka Sekolah (PTS) dalam upaya meningkatkan kompetensi guru kelas dalam proses pembelajaran di kelas senyatanya melalui pelaksanaan supervisi akademik yang dilakukan secara terencana, terorganisir, dan penuh tanggung jawab sehingga mindset guru dalam pembelajaran di kelas dapat ditingkatkan.

- Kepada semua guru kelas dan guru bidang studi di SD Negeri 39 Mataram disarankan agar senantiasa melakukan proses pembelajaran yang baik dan benar berdasarkan kurikulum 2013 sehingga hasil belajar dan prestasi belajar peserta didik dapat ditingkatkan dan KKM yang telah ditetapkan dapat tercapai bahkan dapat dilampaui.

\section{DAFTAR PUSTAKA}

Akhmadsudrajat, 2019. Supervisi Akademik Kepala Sekolah. dalam https://akhmadsudrajat.wordpress.com/20 11/03/04/konsep-supervisi-akademik/, 
diambil tanggal 15 Januari 2019. Pukul 09.25 wita.

Anonim, 2019, pengertian kompetensi guru dalam

http://www.jejakpendidikan.com/2016/1 1/pengertian-kompetensi-guru.html, diambil tanggal 15 Januari 2019. Pukul 10.01 Wita

Anonim, 2019, tugas dan tanggung jawab $K K G$, dalam http://infopendidikan17.blogspot.com/2 015/11/pengertian-tugas-dan-tanggungjawab.html, diambil tanggal 16 Januari 2019 pukul 11.36 wita.

Alexander Mackie College of Advance Education. 1981. Supervision of Practice Teaching. Primary Program, Sydney, Australia.

Cahya Wirawan, 2012, Peningkatan Kompetensi Guru kelas Dalam Pemanfaatan Media Pembelajaran Melalui Mentoring, Jakarta: Jurnal PTK Dikmen

Dodd, W.A. 1972. Primary School Inspection in New Countries. London: Oxford University Press.

Glickman, C.D., Gordon, S.P., and RossGordon, J.M. 2007. Supervision and Instructional Leadership A Development Approach. Seventh Edition. Boston: Perason.

Gwynn, J.M. 1961. Theory and Practice of Supervision. New York: Dodd, Mead \& Company.

Hamatih, 2006, Kurikulum Tingkat Satuan Pendidikan, Bandung: Remaja Rosda Karya.

Mantja, W. 1984. "Efektivitas Supervisi Klinik dalam Pembimbingan Praktek Mengajar Mahasiswa IKIP Malang,"Tesis. FPS IKIP Malang.

Mulyasa, 2007, Kurikulum Tingkat Satuan Pendidikan, Bandung: Remaja Rosda Karya.

Nana Sujana, 2009, Pendidikan Tingkat KePenelitian Konsep Dan Aplikasinya Bagi Peneliti Sekolah, Jakarta: LPP Bina Mitra.

Nasrudin, 2019, Pengertian Proses Pembelajaran, dalam https://nasrudin11.blogspot.com/2018/1 2/pengertian-proses-pembelajaran.html, diambil pada tanggal 19 Januari 2019 pada pukul 20.15 wita

Peraturan Pemerintah Republik Indonesia Nomor 74 Tahun 2008 Tentang Guru

Permendikbud Nomor 103 Tahun 2014 tentang standar proses

Permendikbud Nomor 22 Tahun 2016 tentang standar proses

Robbins, S.P.2008. The Truth about Managing People. Second Edition. Upper Sadle River, New Jersey: Pearson Education, Inc.

Sergiovanni, T.J. 1982. Supervision of Teaching. Alexandria: Association for Supervision and Curriculum Development.

Suharjono, 2009, Melaksanakan Sekolah Sebagai Kegiatan Penelitian Tindakan Sekolah Sebagai Kegiatan Pengembangan Profesi Penelitia Sekolah, Jakarta: Bumi Aksara.

Sullivan, S. \& Glanz, J. 2005. Supervision that Improving Teaching Strategies and Techniques. Thousand Oaks, California: Corwin Press.

Sullivan, S \& Glanz, J. 2005. Supervision that ImprovesTeaching Strategies and Techniques. Thousand Oaks, California: Corwin Press.

Supervisi Akademik dalam peningkatan profesionalisme guru. 2006. Kompetensi Supervisi Kepala Sekolah Pendidikan Dasar. Direktorat Tenaga Kependidikan PMPTK Depdiknas.

Ditjen

Undang-undang Nomor 20 Tahun 2003 Tentang Sistem Pendidikan Nasional Usman, 2005, Menjadi Guru Profesional, Bandung: Remaja Rosda Karya.

Wiles, J. dan J. Bondi. 1986. Supervision: A Guide to Practice . Second Edition. Columbus: Charles E. Merrill Publishing Company

Verma, V.K. 1996. The Human Aspects of Project Management Human Resources Skills for the Project Manager. Volume Two. Harper Darby,PA: Project Management Institute 